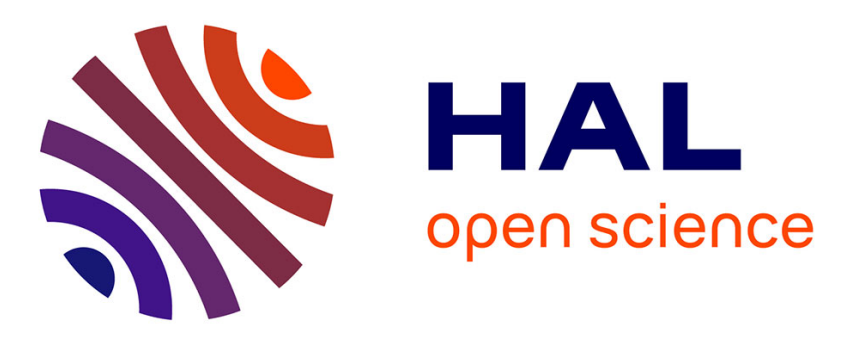

\title{
Generalized biomass equations for the main aboveground biomass components of maritime pine across contrasting environments
}

Shaiek, Loustau, Trichet, Céline Meredieu, Bachtobji, Garchi, Mohamed Aouni

\section{To cite this version:}

Shaiek, Loustau, Trichet, Céline Meredieu, Bachtobji, et al.. Generalized biomass equations for the main aboveground biomass components of maritime pine across contrasting environments. Annals of Forest Science, 2011, 68 (3), pp.443-452. 10.1007/s13595-011-0044-8 . hal-00930779

\section{HAL Id: hal-00930779 https://hal.science/hal-00930779}

Submitted on 1 Jan 2011

HAL is a multi-disciplinary open access archive for the deposit and dissemination of scientific research documents, whether they are published or not. The documents may come from teaching and research institutions in France or abroad, or from public or private research centers.
L'archive ouverte pluridisciplinaire HAL, est destinée au dépôt et à la diffusion de documents scientifiques de niveau recherche, publiés ou non, émanant des établissements d'enseignement et de recherche français ou étrangers, des laboratoires publics ou privés. 


\title{
Generalized biomass equations for the main aboveground biomass components of maritime pine across contrasting environments
}

\author{
Olfa Shaiek • Denis Loustau • Pierre Trichet • \\ Céline Meredieu • Beya Bachtobji • Salah Garchi • \\ Mohamed Hédi EL Aouni
}

Received: 11 November 2009 / Accepted: 11 July 2010 /Published online: 3 May 2011

(C) INRA and Springer Science+Business Media B.V. 2011

\begin{abstract}
- Introduction In order to predict the biomass of aerial components of maritime pine stands (Pinus pinaster Ait.), generalized allometric equations were developed using data collected from the southern and northern margins of its geographical area.

- Methods The data comprised biomass values divided into foliage, branch, stem and minor components collected from 26 trees in Tunisia and 152 trees in France. Some trees were taken from plots receiving fertilisation and irrigation. The equation $W=a D^{b}$, where $W$ is the biomass, $D$ the stem diameter and $a$ and $b$ are fitted parameters, explained $98 \%$ of the variations in the total aerial biomass. The addition of tree age reduced significantly the residual sum of squares for the foliage component. This model explains $79 \%$ of the variations in foliage biomass observed.

- Results To a lesser extent, the age variable also improved the stem and branch models that explain $98 \%$ and $71 \%$ of the observed sum of squares, respectively. Site variables such as the stocking density, stand basal area, fertilisation or annual precipitation did not reduce the residual sum of squares, suggesting that their putative effects are conveyed through tree growth rate.
\end{abstract}

Handling Editor: Reinhart Ceulemans

O. Shaiek • B. Bachtobji · S. Garchi $\cdot$ M. H. EL Aouni

Faculté des Sciences de Bizerte, Laboratoire d'Ecologie Végétale,

Jarzouna 7021, Tunisia

D. Loustau $(\bowtie) \cdot$ P. Trichet $\cdot$ C. Meredieu

INRA, UR1263 EPHYSE,

F-33140 Villenave d'Ornon, France

e-mail: denis.loustau@bordeaux.inra.fr
Keywords Forest biomass $\cdot$ Foliage $\cdot$ Branch $\cdot$ Stem . Allometry

\section{Introduction}

Using allometric equations for estimating biomass and carbon stocks in forests on the basis of simple variables measured in forest inventories is a convenient method long employed by foresters and scientists (Ter-Mikaelian and Korzukhin 1997; Zianis et al. 2005). Allometric equations used for trees are essentially power functions of the stem diameter at a given height (Crow and Laidly 1980; Zianis and Mencuccini 2003; Kajimoto et al. 2006; Muukkonen 2007; Socha and Wezyk 2007). The rationale of such a model was analysed in terms of proportionality of the relative growth rate between stem diameter, height and compartment and total biomass (Enquist 2002). These equations have been applied to predict the total biomass and its aboveground and belowground components (Baldwin et al. 1997; Makela and Vanninen 1998; Ritson and Sochacki 2003). Additional variables such as the height or age of the trees have been shown to improve the predictability of sitespecific models (Porté et al. 2002; Trichet et al. 2008; Wang 2006; King et al. 2007).

The calibration of biomass equations to be generalized over large regions needs to be based upon a sample of site and climate conditions that encompasses the range of environmental conditions covered. Among the environmental factors under consideration, the nutrient and water availabilities and the social status of trees are known to modify the growth rate and the tree and crown shape, respectively. Whether allometric relationships vary accord- 
ing to such factors is under debate. They may therefore be taken into account when constructing allometric equations to estimate biomass or carbon stocks over large areas.

Generalized biomass equations constructed from a dataset including different sites have been established for different European and North American tree species in order to calculate biomass and carbon stocks across large geographic areas (Schmitt and Grigal 1981; Pastor et al. 1984; Marklund 1987; Lambert et al. 2005). This approach can also be used to evaluate the generality of biomass allometric equations and identify the site factors which may modify such relationships. For instance, Muukkonen (2007) explained that $64-99 \%$ of the total aboveground biomass and its components for five broadleaved and coniferous species in Europe with models only based upon the diameter at breast height. Also, the generalized foliar biomass of Pinus strobus based only upon the stem diameter developed by Levia (2008) explained $97 \%$ of its variance.

In this study, we have examined biomass equations for maritime pine, Pinus pinaster Ait., a European southern pine species that has a natural area extending from North Africa to South of France and which grows in a climate ranging from Mediterranean to temperate Atlantic. It is mainly used for wood, biomass and pulp production and covers 4 million hectares in southern Europe. Some sitespecific allometric equations have been established for this species in France (Lemoine et al. 1986; Porté et al. 2000; 2002; Trichet et al. 2008), Spain (Merino et al. 2005) and Australia (Ritson and Sochacki 2003), but no attempt has yet been made to generalise these equations on a larger scale. The aim of this study was to generalize allometric equations for maritime pine across much of its natural growing range in Europe and North Africa.

\section{Material and methods}

\subsection{Sites}

Our analysis is made on 178 maritime pine (P. pinaster Ait.) trees sampled on nine sites spread between the northern (France) and southern (Tunisia) limits of its natural area. Table 1 summarises the main site and stand characteristics.

In France, the biomass data were collected from four managed even-aged stands where 152 trees were felled on different dates between 1996 (Bray site) and 2004 (Hermitage-L12). One of the sites, Hermitage-L, was sampled at the ages of nine (2001) and 12 (2004), respectively. Hermitage- $\mathrm{L}$ is a fertilisation-irrigation experiment which was begun in 1997 and which is described by Trichet et al. (2008). It comprises four complete randomised blocks where two levels of irrigation and three levels of fertilisation are combined. These treatments were applied annually from 1997 to 2008 . The trees sampled in this site were taken from the six different treatment combinations, including the control plots, and were pooled in six composite plots. All other stands were managed according to regional guidelines with 5 -year periodic thinnings between the ages of 15 and 35 and the final clearcut at the age of 40 to 50 .

In Tunisia, 26 trees were sampled from six different plots located in the northern mounts forming the Mediterranean littoral. The sites cover a range of soils from podzolic soils (Malloula 1 and 2) to brown luvic (Tbeinia) and calcareous sands on ancient dunes (Saounia, Ouechtata, Rimel). The forest stand at Malloula was naturally regenerated and is a mixture of different age classes and species, whereas the five other stands were artificially regenerated. No thinning, fertilisation or irrigation was applied in Tunisian stands.

\subsection{Biomass and tree measurements}

In each plot, a sample of trees was chosen to cover the observed range of trunk diameter at breast height $(1.30 \mathrm{~m})$. The protocol for collecting trees on the French sites is described in detail by Porté et al. (2002), Bert and Danjon (2006) and Trichet et al. (2008) for the Bray, Bilos and Hermitage-L site, respectively. Trees sampled were felled and separated into biomass components. Subsamples of each component were then dried at $65^{\circ} \mathrm{C}$ and weighed. On Tunisian sites, branch and foliage biomasses were estimated by applying values of water content and needle to branch ratio measured on one representative branch per whorl to the fresh weight of the total branch+foliage of each whorl. This was then summed over the entire crown. The total bud and cone biomass was estimated with the same method. For each whorl, the ratio of their biomass to the total branch biomass was measured on a representative branch, applied to the rest of the whorl branches, and then summed over the crown. The trunk was cut into $1-\mathrm{m}-\operatorname{long} \operatorname{logs}$ that were weighed immediately. The wood and bark dry weights were then determined from the bark to wood ratio and humidity content determined in the laboratory from a stem disk taken from the middle of the log. Biomass values are all dry weights at $65^{\circ} \mathrm{C}$.

\section{Models}

In order to keep the model as simple as possible, we first tested the allometric general equation:

$W_{\mathrm{i}, \mathrm{j}}=\mathrm{a}_{\mathrm{i}} D_{\mathrm{j}}^{b \mathrm{i}}+e_{\mathrm{i}, \mathrm{j}}$,

where $W_{\mathrm{i}, \mathrm{j}}$ is the biomass of compartment $i$ of tree $j$ (kilograms per tree), $a_{\mathrm{i}}$ and $b_{\mathrm{i}}$ are model parameters to fit by non-linear regression, $D_{\mathrm{j}}$ the diameter at breast height 


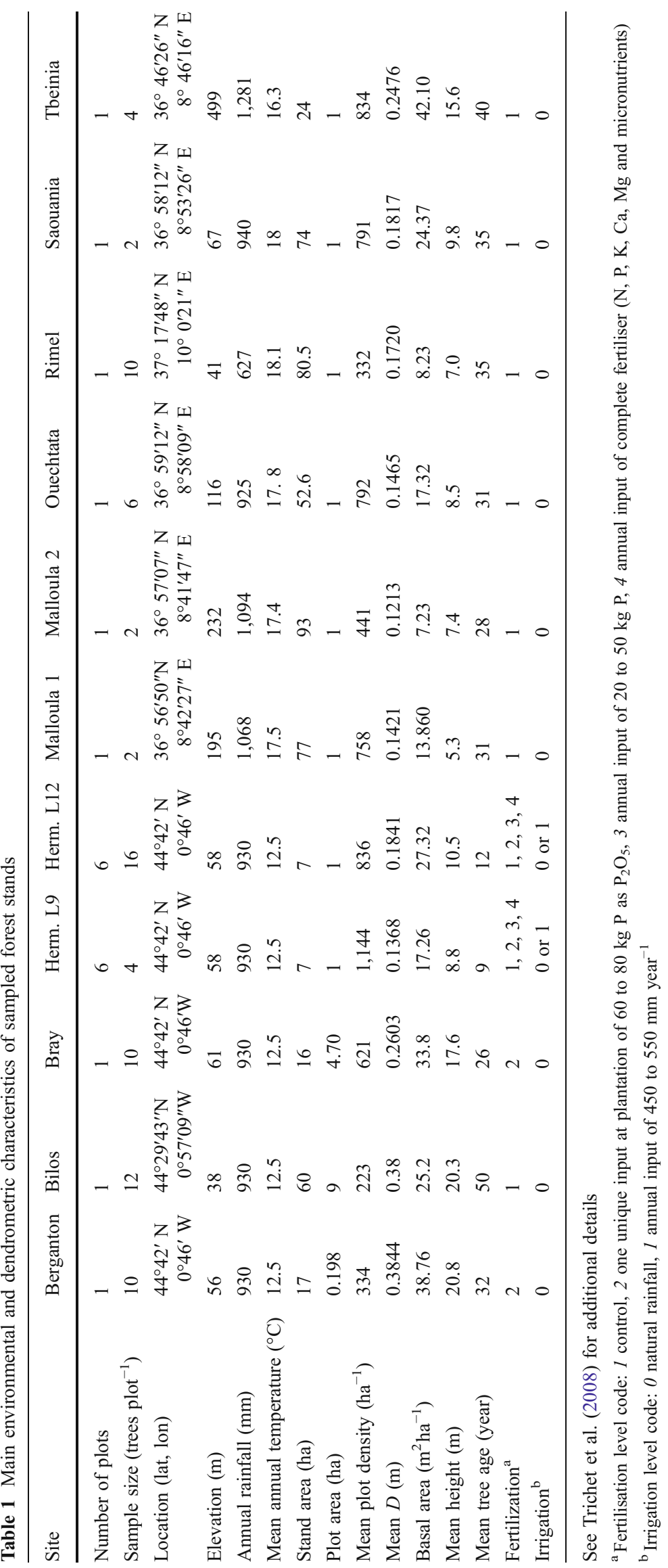


(meter) and $\varepsilon_{\mathrm{i}, \mathrm{j}}$ the error term. In order to give an even weight to every plot sampled, each observation was weighted by $1 / n$, where $n$ is the number of trees sampled. For normalising the error distribution, we used a transformed form of Eq. 1 multiplying the two sides of equation by $D_{\mathrm{j}}^{-2}$ as follows:

$W_{\mathrm{i}, \mathrm{j}} \cdot D_{\mathrm{j}}^{-2}=\left(\mathrm{a}_{\mathrm{i}} D_{\mathrm{j}}^{b \mathrm{i}}+e_{\mathrm{i}, \mathrm{j}}\right) \cdot D_{\mathrm{j}}^{-2}$

We checked the residual distribution homogeneity visually and its normality with the Kolmogorov-Smirnov's test. Following Parresol (1999), it would be mathematically more exact to optimise the power value of the transforming variable $D_{\mathrm{j}}$ (Ritson and Sochacki 2003; Saint-Andre et al. 2005; Antonio et al. 2007). Fixing this value at -2 allows a correct normality of model residuals and did not substantially affect the values estimated for model parameters $a$ and $b$. Two additional explanatory variables, the total tree height, $H_{\mathrm{i}}$, and tree age, $A_{\mathrm{i}}$, were added to the model Eq. 2 as follows:

$W_{\mathrm{i}, \mathrm{j}} \cdot D_{\mathrm{i}}^{-2}=\left(\mathrm{a}_{\mathrm{i}} D_{\mathrm{i}}^{b \mathrm{i}} H_{\mathrm{j}}^{c \mathrm{i}}+e_{\mathrm{i}, \mathrm{j}}\right) \cdot D_{\mathrm{i}}^{-2}$

$W_{\mathrm{i}, \mathrm{j}} \cdot D_{\mathrm{i}}^{-2}=\left(\mathrm{a}_{\mathrm{i}} D_{\mathrm{i}}^{b \mathrm{i}} A_{\mathrm{j}}^{d \mathrm{i}}+e_{\mathrm{i}, \mathrm{j}}\right) \cdot D_{\mathrm{i}}^{-2}$

The influence of additional effects, such as the annual amount of water precipitated (rainfall+irrigation), fertilisation level, latitude, or stand structure variables (stocking density and basal area), was analysed on the model residual values retained for each biomass component (Eqs. 2, 3 or 4). Statistical analyses were carried out using the NLIN and GLM procedures of the statistical software package SAS version 9.2 .

\section{Results}

The range of data collected for subsequent analysis can be visualised in Fig. 1.

The model predictions and observed data shown in Fig. 2 and Table 2 give the parameter values together with their asymptotic errors and normality test results. Only the results of the weighted model with standardised residuals (Eqs. 2, 3 and 4) are shown. The standardised residual graphs included in the Fig. 1 graphs do not visually reveal a systematic departure from homoscedasticity. The models used for individual biomass components and total aboveground biomass were not constrained a priori for fulfilling the additivity criteria (Parresol 2001). However, the linear regression equation between the total biomass estimate and the sum of the biomass components has a slope of 1.016 $\left(R^{2}=0.999\right)$ so that both estimates are consistent, and the

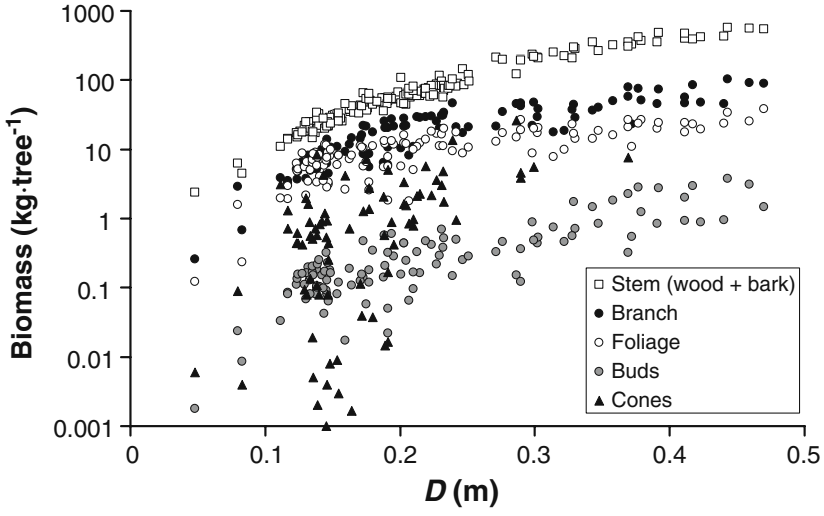

Fig. 1 Biomass values of aboveground components in relationship with diameter at breast height $(D)$ for the entire data set obtained. $Y$ axis is on a logarithmic scale

additivity of the obtained predictive equations is verified a posteriori (Fig. 3).

For the main biomass components, the model asymptotic sum of squares reach $80 \%$ to $98 \%$ of the total sum of squares. Asymptotic errors on parameters $a, b, c$ and $d$ are correspondingly small (Table 2). The allometric Eq. 1 with only $D$ sufficed to capture the aboveground biomass variations among sites and trees. For the other main biomass components - branch, stem, and foliage - the sum of squares of the standardised residual was significantly reduced when the age was introduced in the model (Eq. 3) and so for stemwood, the tree height (Eq. 4; Table 2). Residual distribution was not significantly different from the normal distribution for the main biomass compartments.

Tree age has the strongest effect on the needle biomass: the addition of the tree age variable to the model reduces the residual sum of squares (Table 2) by one quarter, the model sum of squares rising from $71 \%$ to $79 \%$ of the total sum of squares. The age effect is negative for foliage and branches, indicating that older trees support less foliage and branch biomasses than younger trees of the same stem diameter. Conversely, the age effect is positive for the stem biomass model, which is consistent with the wood density increase and age-related change in biomass allocation observed with age in most pine tree species.

The between-site variation of the aboveground biomass$D$ relationship is not visually significant. Similarly, the visual examination of residual graphs for the stem, branch and aboveground components does not reveal any trend according to the climate variables, air temperature or annual rainfall+irrigation (see examples for aboveground biomass and foliage in Figs. 4 and 5). The geographic location also has no effect. The analysis of the environmental and stand structure effects on back-transformed residuals (Table 3) shows that only the fertilisation level had a statistically significant effect. This effect only concerned the branch and 

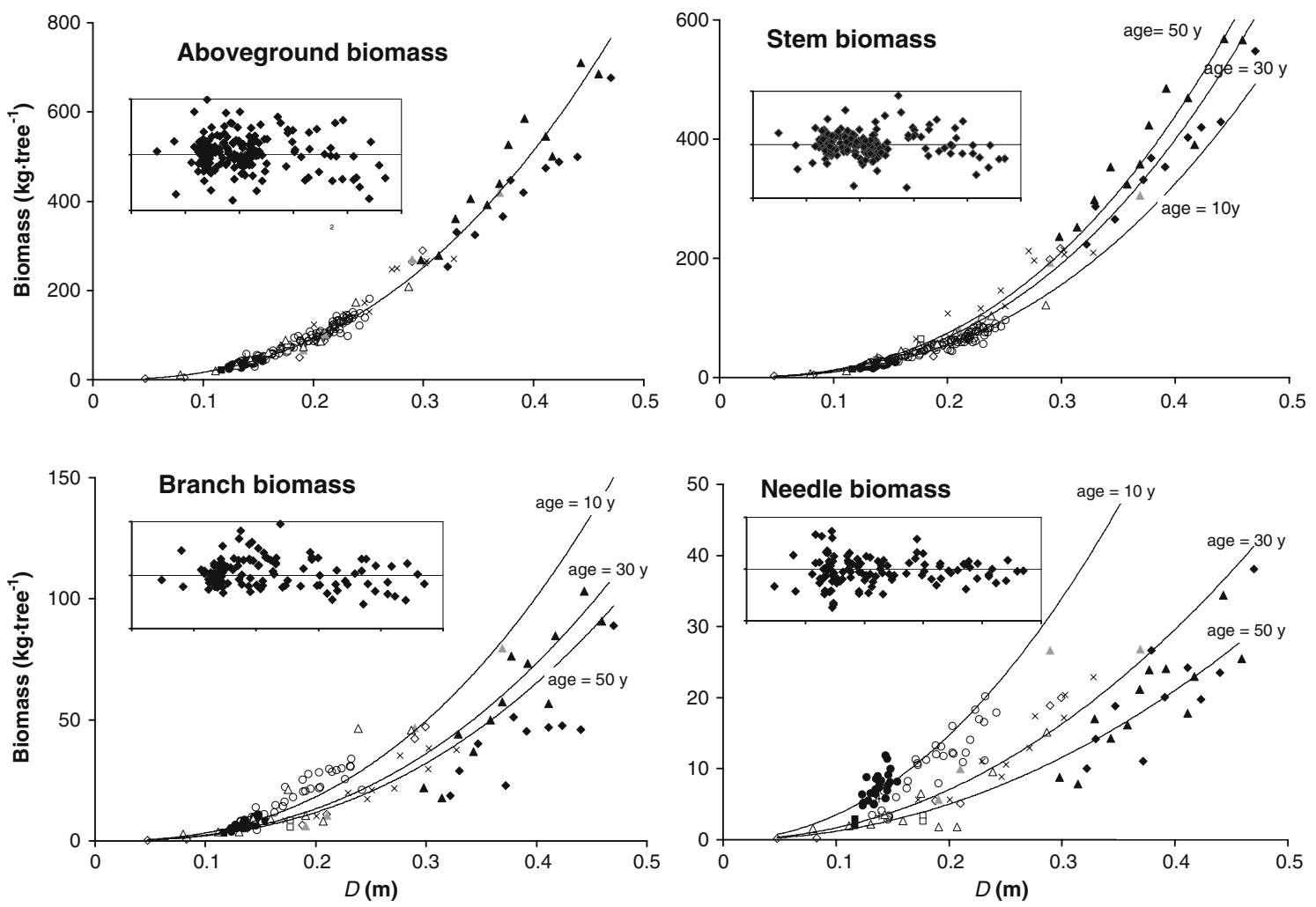

\begin{tabular}{|c|c|c|c|c|c|}
\hline - Berganton & $\Delta$ Bilos & $\times$ Bray & $\circ$ L12 & - L9 & + Malloula1 \\
\hline - Malloula 2 & $\diamond$ Ouechtata & • Saouania & $\triangle$ Tbeinia & $\triangle$ Rimel & \\
\hline
\end{tabular}

Fig. 2 Allometric best models fitted for the stem, branch, needle and total aboveground compartment together with observed data. The effect of tree age was introduced as: $W=a D^{\mathrm{b}} \mathrm{Age}^{\mathrm{c}}$ apart from the aboveground biomass model where it was not significant. The curves show model prediction at the age of 10,30 and 50 , respectively

fertilisation and rainfall or irrigation impacts the trees in that a given stem diameter is reached at a younger age, i.e. faster growth. Introducing height as a supplement variable only reduces the residual sum of squares of the stem model, and this effect is marginal.

\section{Discussion}

Our dataset assembles the data available so far in France and Tunisia; the southern and northern limits of the geographical area of maritime Pine, respectively. This does not include the Lemoine et al. (1986) data, as it unfortunately could not be recovered, and it excludes trees younger than 8 years old that have not yet developed a bole free of branches. The oldest tree collected was 53 years old, and our conclusions are therefore limited to the age range of 8 to 53 years old and to the diameter range shown in Fig. 1 . The dataset includes manipulation experiments in France where the foliar nitrogen content and annual precipitation were augmented to values $60 \%$ higher than the maximum increase in water and nutrient availabilities created by 
Table 2 Values of parameters of the allometric equations fitted to the biomass data set collected over ten sites across France and Tunisian sites ( $n=178$ trees), together with their asymptotic standard error (smaller font)

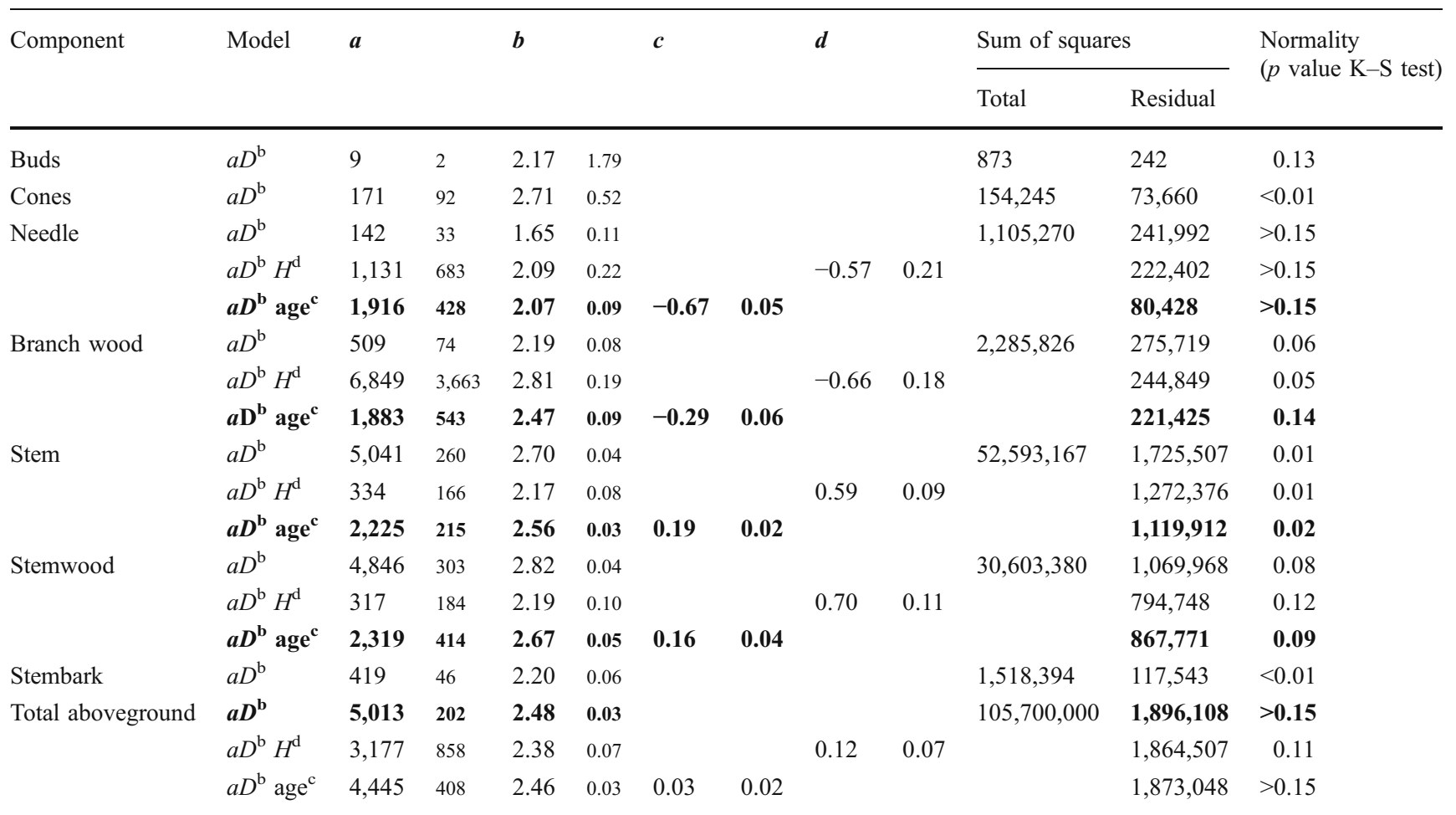

Total and residual sum of squares of each model are given and $p$ value of the Kolmogorov-Smirnov's test of normality for the residual distribution ( $p$ values lower than .05 indicate a departure from a normal distribution). The parameter values of the models shown in Fig. 1 are in bold

observed in natural conditions: $1.6(0.9) \mathrm{mg} \mathrm{N}$ g needle dry matter $^{-1}$ and 1,500 (900) $\mathrm{mm} \mathrm{year}^{-1}$ for the fertilised (control) nitrogen foliar content and irrigated (control) annual precipitation, respectively (Trichet et al. 2008). Thus, this range covers most of the natural conditions of the natural geographical area for this species, apart from the driest conditions in central Spain where precipitations as low as $500 \mathrm{~mm}_{\text {year }}{ }^{-1}$ are observed.

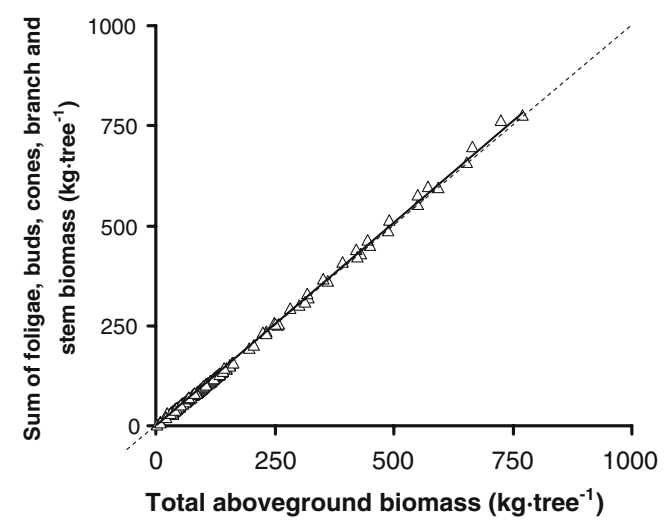

Fig. 3 Plot of the sum of predicted values of the biomass components versus total aboveground biomass estimates (1:1 line/broken line; linear regression bold line). Values are produced by the models retained and corresponding values are given in bold font in Table 1
Following previous surveys, we have chosen to analyse the allometric equation introducing a two-way biomass equation based upon the diameter at breast height and at either age or tree height (Zianis and Mencuccini 2003; Antonio et al. 2007; Cienciala et al. 2006; Peichl and Arain 2007; Hu and Wang 2008; Kaitaniemi and Lintunen 2008; Pajtik et al. 2008). Each of these variables is currently being measured by National Forest Inventories across Europe, thus enabling our results to be used for estimating biomass and carbon stocks in maritime pine forests. It is argued that tree age is difficult to measure, but we stress the fact that it is relatively easy to estimate for pines up to 40 years by visual analysis of the stem. In addition, the age effect on biomass estimates is small beyond that age: the derivation of Eq. 3 shows that an error of 5 years on the tree age would then lead to a bias of $2 \%, 3 \%$, and $5 \%$ on the stem, branch and foliage biomasses, respectively.

The generalized biomass equation modelled for the aboveground part appeared to be unique and unaffected by site conditions (rainfall regime, climate, soil type), silvicultural practices (stocking density, fertilisation) or geographical provenance (Antonio et al. 2007), contrary to studies showing that biomass allometric equations are climate-specific (Callaway et al. 1994; Delucia et al. 2000; Lopez-Serrano et al. 2005). We think the cause of this discrepancy is that these latter surveys were based upon a 

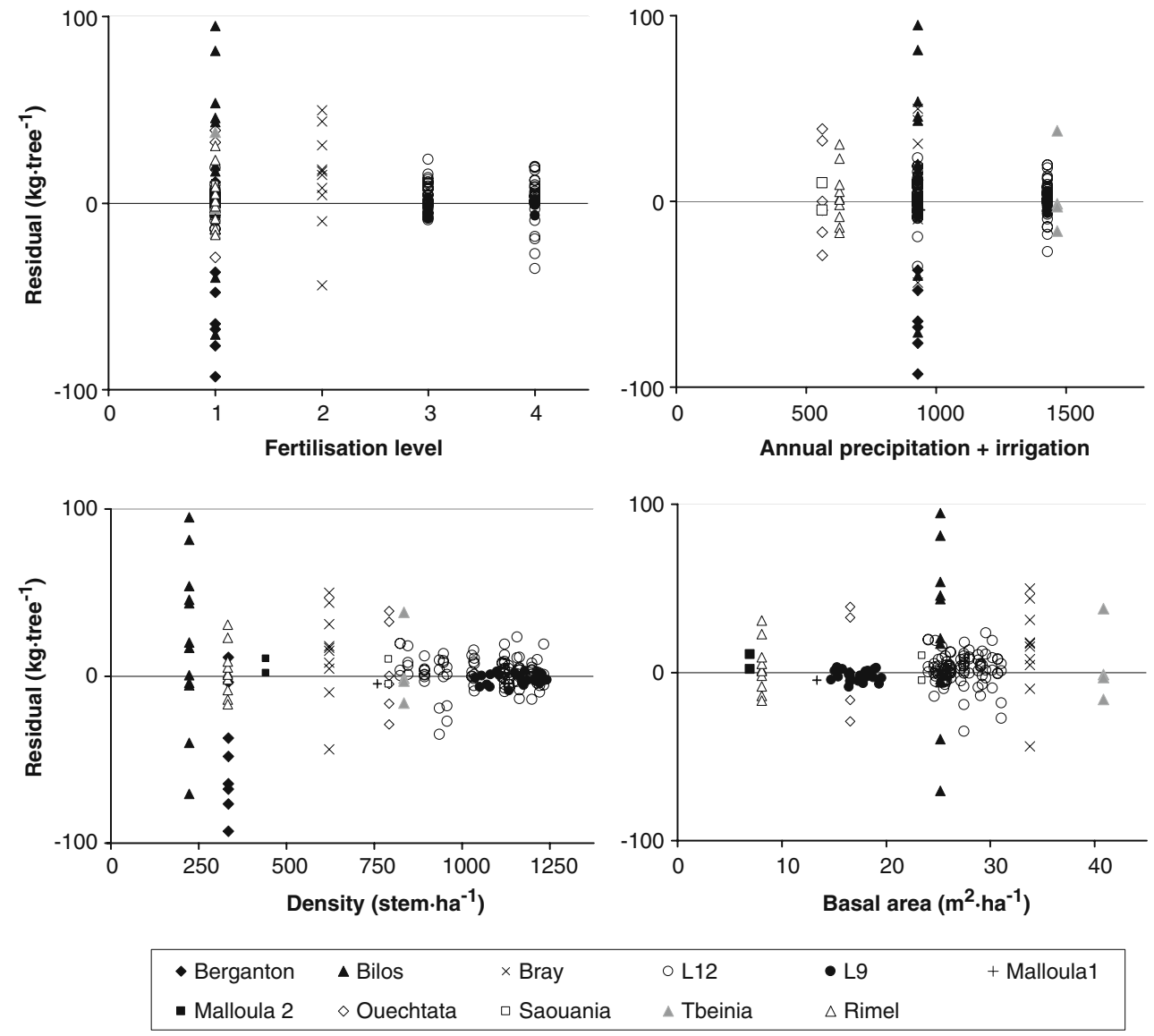

Fig. 4 Plots of the raw residual values of allometric model of aboveground biomass shown in Fig. 1 against environmental and stand variables: fertilisation level, annual precipitation+irrigation, stocking density and basal area

limited number of contrasted sites with regards to e.g. the precipitation regime. The strength of this aboveground biomass $-D$ relationship suggests that it may be used for inventorying biomass and carbon stock using inventory data across the whole species area, regardless of the site and climate conditions. A noticeable exception was however reported by Ritson and Sochacki (2003) for wind effects in southwestern Australia, where trees grown in open spaces were found to be slightly denser and heavier than trees located in closed stands. For estimating biomass and carbon stock, generalized biomass equations may be advantageous over volume equations that need highly uncertain conversion and expansion factors (Nabuurs et al. 2004; Vallet et al. 2006). The model fit to the above aboveground and stem biomass explains $97 \%$ of the variance observed in the data set used, a value currently reached in similar studies (Cienciala et al. 2006; Muukkonen 2007). We observe that a unique $D$-biomass relationship holds

Table 3 Determination coefficients $\left(R^{2}\right)$ of linear models including effects of fertilisation level, annual precipitation, stocking density and basal area on the residuals of best allometric models (Eq. 1 or 3) selected for the main biomass components (shown in Fig. 1)

\begin{tabular}{lllll}
$\begin{array}{l}\text { Allometric model } \\
\text { equation }\end{array}$ & \multicolumn{1}{l}{ Effects } & & \\
\cline { 2 - 5 } & Fertilisation & Precipitation & Basal area & Stocking density \\
\hline$(4)$ & n.s. & n.s. & n.s. & n.s. \\
$(4)$ & n.s. & 0.09 & n.s. & n.s. \\
$(4)$ & n.s. & 0.14 & n.s. & n.s. \\
$(2)$ & n.s. & n.s. & n.s. & n.s. \\
\hline
\end{tabular}

Each effect was tested separately

n.s. not significant 

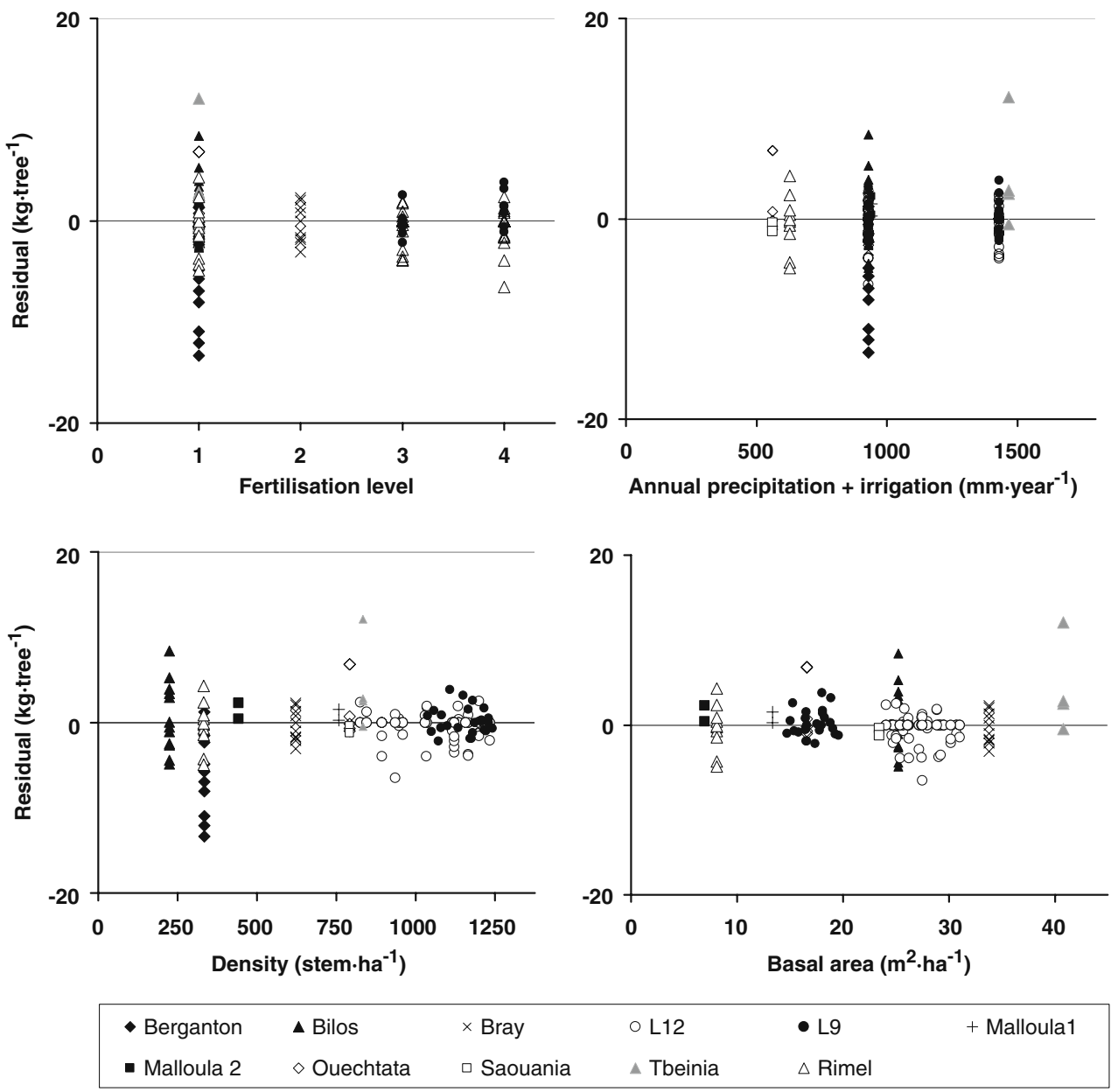

Fig. 5 Plots of the raw residual values of allometric model of foliage biomass shown in Fig. 2 against environmental and stand variables: fertilisation level, annual precipitation+irrigation, stocking density and basal area

only for the total aboveground biomass whereas additional variables are required for estimating component biomass albeit with a higher error (Antonio et al. 2007). This may support the hypothesis of an invariant allometric relationship due to mechanical constraint, i.e. a given stem thickness must be reached for supporting a given mechanical stress (Niklas and Spatz 2004). Since maritime pine essentially grows over littoral areas exposed to strong winds, it would be interesting to investigate the allometry for pines exposed at different wind regimes.

In addition, we show that the age of tree brings a significant amount of additional information for estimating the biomass of the stem, foliage and branch compartments, confirming previous findings on this species reported in site-specific studies by Porté et al. (2002), Ritson and Sochacki (2003) and Balboa-Murias et al. (2006). A changing allometry scheme with age has also been reported in boreal species (Bond-Lamberty et al. 2002) or Eucalyptus (Saint-Andre et al. 2005; Antonio et al. 2007) and pine species (Socha and Wezyk 2007). Mathematically, it implies that the linear relationship between the relative growth rates of stem radius and biomass components has an intercept proportional to $1 /$ age. In other words, it allows for a changing allocation into foliage, stem and branch component along the tree development whereas model Eq. 2 implies a constant proportionality between the relative growth rates of plant parts whatever the tree age. Such an age effect is not surprising for maritime Pine whose growth is constrained by a strong age-related effect on hydraulic architecture, and therefore, a diminishing foliage/sapwood ratio with age (Delzon et al. 2004; Niklas and Spatz 2004).

It is important to account for age effect on foliage, branch and stem allometry because this species exhibits a large range of growth rates across the area from Europe to Tunisia, where it can be either grown naturally in unmanaged forests or artificially in intensively managed stands with site preparation, fertilisation and periodic thinning. At this spatial scale, the tree age and size become weakly correlated: a given diameter at breast height can be 
reached at a large range of ages. The supplementary information brought by age in the allometric model is also shown indirectly by the asymptotic correlation coefficients between model parameters, $a, b$ and $c$ in Eq. 3 that are weaker than between $a, b$ and $d$ of Eq. 4 (data not shown).

It is noteworthy that age explains entirely the effects of fertilisation and precipitation on the model residuals for the foliage and branch compartments. This suggests that nutrition and water affect the growth rate, but not the tree ontogeny itself. It also suggests that the higher foliage and branch biomass in fertile sites result essentially from a faster growth and not a change in the fundamental morphometric model of the species (Trichet et al. 2008). Gower et al. (1993) on Pinus resinosa and Pinus ponderosa came to the same conclusion, as well as Coyle and Coleman (2005) for irrigated and fertilised cottonwood clones and sycamore. We are aware that a number of other authors report a significant interaction of environmental and stand variables on the allometry of coniferous species (Beets and Madgwick 1988; Callaway et al. 1994; Delucia et al. 2000 among others). We conclude that for the case of maritime Pine - a shade-intolerant species with a limited social position range - tree age is a variable that may well capture most of these effects.

Acknowledgements This work was achieved during the first author's $\mathrm{Ph} \mathrm{D}$. thesis work in Tunisia supported by a fellowship of the Université 7 Novembre Carthage (Faculté de Bizerte), as well as partly in France funded by INRA, EFPA department and Bordeaux-1 University. This work was achieved within the framework of the Région Aquitaine project "Durabilité de la filière Forêt-Bois de Pin maritime". The European projects Carbo-Age (FP5) and Carboeurope (FP6) supported the data collection carried out at the Bray, Hermitage $\mathrm{L}$ and Bilos sites. A. Porté, D. Bert, F. Danjon, (INRA, UMR Biogeco), F. Bernier (INRA, UE Hermitage) and Tunisian and French technicians participated in the morphometric and biomass measurements.

\section{References}

Antonio N, Tome M, Tome J, Soares P, Fontes L (2007) Effect of tree, stand, and site variables on the allometry of Eucalyptus globulus tree biomass. Can J For Res 37(5):895-906

Balboa-Murias MA, Rodriguez-Soalleiro R, Merino A, AlvarezGonzalez JG (2006) Temporal variations and distribution of carbon stocks in aboveground biomass of radiata pine and maritime pine pure stands under different silvicultural alternatives. For Ecol Manag 237(1-3):29-38

Baldwin VC, Peterson KD, Burkhart HE, Amateis RL, Dougherty PM (1997) Equations for estimating loblolly pine branch and foliage weight and surface area distributions. Can J For Res 27(6): 918927

Beets PN, Madgwick HAI (1988) Above-ground dry matter and nutrient content of Pinus radiata as affected by lupin, fertilizer, thinning, and stand age. NZ J Forest Sci 18(1):43-64

Bert D, Danjon F (2006) Carbon concentration variations in the roots, stem and crown of mature Pinus pinaster (Ait). For Ecol Manag 222(1-3):279-295
Bond-Lamberty B, Wang C, Gower ST (2002) Aboveground and belowground biomass and sapwood area allometric equations for six boreal tree species of northern Manitoba. Can J For Res 32 (8):1441-1450

Callaway RM, Delucia EH, Schlesinger WH (1994) Biomass allocation of montane and desert ponderosa pine - an analog for response to climate-change. Ecology 75(5):1474-1481

Cienciala E, Cerny M, Tatarinov F, Apltauer J, Exnerova Z (2006) Biomass functions applicable to Scots pine. Trees-Struct Funct 20(4):483-495

Coyle DR, Coleman MD (2005) Forest production responses to irrigation and fertilization are not explained by shifts in allocation. For Ecol Manag 208(1-3):137-152

Crow TR, Laidly PR (1980) Alternative models for estimating woody plant biomass. Can J For Res 10(3):367-370

DeLucia EH, Maherali H, Carey EV (2000) Climate-driven changes in biomass allocation in pines. Glob Chang Biol 6(5):587-593

Delzon S, Sartore M, Burlett R, Dewar R, Loustau D (2004) Hydraulic responses to height growth in maritime pine trees. Plant Cell Environ 27(9):1077-1087

Enquist BJ (2002) Universal scaling in tree and vascular plant allometry: toward a general quantitative theory linking plant form and function from cells to ecosystems. Tree Physiol 22(1516): 1045-1064

Gower ST, Haynes BE, Fassnacht KS, Running SW, Hunt ER (1993) Influence of fertilization on the allometric relations for two pines in contrasting environments. Can J For Res 23(8):1704-1711

$\mathrm{Hu}$ HF, Wang GG (2008) Changes in forest biomass carbon storage in the South Carolina Piedmont between 1936 and 2005. For Ecol Manag 255(5-6):1400-1408

Kaitaniemi P, Lintunen A (2008) Precision of allometric scaling equations for trees can be improved by including the effect of ecological interactions. Trees 22(4):579-584

Kajimoto T, Matsuura Y, Osawa A, Abaimov AP, Zyryanova OA, Isaev AP, Yefremov DP, Mori S, Koike T (2006) Size-mass allometry and biomass allocation of two larch species growing on the continuous permafrost region in Siberia. For Ecol Manag 222 (1-3):314-325

King JS, Giardina CP, Pregitzer KS, Friend AL (2007) Biomass partitioning in red pine (Pinus resinosa) along a chronosequence in the Upper Peninsula of Michigan. Can J For Res 37(1):93-102

Lambert MC, Ung CH, Raulier F (2005) Canadian national tree aboveground biomass equations. Can J For Res 35(8):1996-2018

Lemoine B, Gelpe J, Ranger J, Nys C (1986) Biomasses et croissance du pin maritime. Etude de la variabilité dans un peuplement de 16 ans. Ann Sci For 43(1):67-84

Levia DF (2008) A generalized allometric equation to predict foliar dry weight on the basis of trunk diameter for eastern white pine (Pinus strobus L). For Ecol Manag 255(5/6):1789-1792

Lopez-Serrano FR, Garcia-Morote A, Andres-Abellan M, Tendero A, del Cerro A (2005) Site and weather effects in allometries: a simple approach to climate change effect on pines. For Ecol Manag 215(1-3):251-270

Makela A, Vanninen P (1998) Impacts of size and competition on tree form and distribution of aboveground biomass in Scots pine. Can J For Res 28(2):216-227

Marklund LG (1987) Biomass functions for Norway spruce (Picea abies (L.) Karst) in Sweden. Sveriges lantbruksuniversitet, Rapporter-Skog 43:1-127

Merino A, Balboa MA, Rodríguez SR, Álvarez González JG (2005) Nutrient exports under different harvesting regimes in fastgrowing forest plantations in southern Europe. For Ecol Manag 207(3):325-339

Muukkonen P (2007) Generalized allometric volume and biomass equations for some tree species in Europe. Eur J For Res 126 (2):157-166 
Nabuurs G-J, Ravindranath NH, Paustian K, Freibauer A, Hohenstein W, Makundi W (2004) Chapter 3. LUCF sector good practice guidance. In: Penman J, Gytarsky M, Hiraishi T et al (eds) Good practice guidance for land use, land use change and forestry. Institute for Global Environmental Strategies (for the IPCC), Kanagawa, p 312

Niklas KJ, Spatz HC (2004) Growth and hydraulic (not mechanical) constraints govern the scaling of tree height and mass. Proc Natl Acad Sci USA 101(44):15661-15663

Pajtik J, Konopka B, Lukac M (2008) Biomass functions and expansion factors in young Norway spruce (Picea abies [L.] Karst) trees. For Ecol Manag 256(5):1096-1103

Parresol BR (1999) Assessing tree and stand biomass: a review with examples and critical comparisons. For Sci 45(4):573-593

Parresol BR (2001) Additivity of nonlinear biomass equations. Can J For Res 31(5):865-878

Pastor J, Aber JD, Melillo JM (1984) Biomass prediction using generalized allometric regressions for some northeast tree species. For Ecol Manag 7(4):265-274

Peichl M, Arain MA (2007) Allometry and partitioning of above- and belowground tree biomass in an age-sequence of white pine forests. For Ecol Manag 253(1-3):68-80

Porté A, Bosc A, Champion I, Loustau D (2000) Estimating the foliage biomass and area of maritime Pine (Pinus pinaster Ait.) branches and crowns with application to modelling the foliage area distribution in the crown. Ann Sci For 57(1):73-86

Porté A, Trichet P, Bert D, Loustau D (2002) Allometric relationships for branch and tree woody biomass of maritime pine (Pinus pinaster Ait.). For Ecol Manag 158(1-3):71-83

Ritson P, Sochacki S (2003) Measurement and prediction of biomass and carbon content of Pinus pinaster trees in farm forestry plantations, south-western Australia. For Ecol Manag 175(1-3):103-117
Saint-Andre L, M'Bou AT, Mabiala A, Mouvondy W, Jourdan C, Roupsard O, Deleporte P, Hamel O, Nouvellon Y (2005) Agerelated equations for above- and below-ground biomass of a Eucalyptus hybrid in Congo. For Ecol Manag 205(1-3):199214

Schmitt MDC, Grigal DF (1981) Generalized Biomass Estimation Equations for Betula-Papyrifera Marsh. Can J For Res 11(4): $837-840$

Socha J, Wezyk P (2007) Allometric equations for estimating the foliage biomass of Scots pine. Eur J For Res 126(2):263-270

Ter-Mikaelian MT, Korzukhin MD (1997) Biomass equations for sixty-five North American tree species. For Ecol Manag 97:124

Trichet P, Loustau D, Lambort C, Linder S (2008) Manipulating nutrient and water availability in a maritime pine plantation: effects on growth, production, and biomass allocation at canopy closure. Ann For Sci 65(8):814

Vallet P, Dhote J-F, Moguedec GL, Ravart M, Pignard G (2006) Development of total aboveground volume equations for seven important forest tree species in France. For Ecol Manag 229(13):98-110

Wang CK (2006) Biomass allometric equations for 10 co-occurring tree species in Chinese temperate forests. For Ecol Manag 222 $(1-3): 9-16$

Zianis D, Mencuccini M (2003) Aboveground biomass relationships for beech (Fagus moesiaca Cz.) trees in Vermio Mountain, Northern Greece, and generalised equations for Fagus sp. Ann For Sci 60(5):439-448

Zianis D, Muukkonen P, Mäkipää R, Mencuccini M (2005) Biomass and stem volume equations for tree species in Europe. Silva Fenn Monogr 4:2-63 